\title{
Variation Between Community and Hospital Acquired Methicillin Resistant Coagulase-Positive Staphylococcus Isolates from The Nasal Carriage in The Central Region of Saudi Arabia
}

Hazem Aqel ( $\square$ aqelh@ksau-hs.edu.sa )

King Saud bin Abdulaziz University for Health Sciences

Sameera Al Johani

King Saud bin Abdulaziz University for Health Sciences

Norah Abu Khalid

King Saud bin Abdulaziz University for Health Sciences

Hajeer Al Shammari

King Saud bin Abdulaziz University for Health Sciences

Dema Al Koblan

King Saud bin Abdulaziz University for Health Sciences

Shatha Al Jambi

King Saud bin Abdulaziz University for Health Sciences

Wejdan Al Waeel

King Saud bin Abdulaziz University for Health Sciences

Nouf Al Bokhari

King Saud bin Abdulaziz University for Health Sciences

Etzaz Al Outaibi

King Saud bin Abdulaziz University for Health Sciences

Razan Emam

King Saud bin Abdulaziz University for Health Sciences

\section{Research Article}

Keywords: Methicillin-resistant coagulase positive staphylococcus, Antimicrobial susceptibility test, Community, Hospital, Polymerase chain reactions.

Posted Date: June 14th, 2021

DOI: https://doi.org/10.21203/rs.3.rs-574816/v1 
License: (c) (i) This work is licensed under a Creative Commons Attribution 4.0 International License. Read Full License 


\section{Abstract \\ Background}

The coagulase-positive staphylococcus (CoPS) has become progressively prevailing in both community and hospital. The variation between community and hospital acquired methicillin resistant coagulase positive staphylococcus has been used to monitor decisions about realistic therapy.

\section{Methods}

Participants presenting with culture proven coagulase positive staphylococcus from the nose were enclosed during this study. Antibiotic susceptibility test was verified by exploiting the E-test and disk diffusion methods. Eleven toxin genes had been analyzed using a polymerase chain reaction.

\section{Results}

The oxacillin-resistant E-test showed extremely vital resistance in hospital-isolates (34.5\%) than in community-isolates $(19.2 \%)(p$-value $=0.009)$. The most effective antibiotic against community acquired CoPS is a quinupristin followed by vancomycin and rifampin then clindamycin. Whereas, clindamycin, sulfamethoxazole/trimethoprim, rifampin, and quinupristin seem to be more effective against hospital acquired CoPS. The intermediate effects of both cefoxitin and vancomycin were highly significant in hospital acquired CoPS isolates compared with hospital acquired CoPS isolates ( $p$-value $=0.009$ and 0.005). The proven methicillin resistance coagulase positive staphylococcus (MRCoPS) was subjected for detection the following toxin embp (480 bp), aap (180 bp, 200 bp, 300 bp, 460 bp, and 480 bp), and aae (110 bp) genes that were present only in a community acquired MRCoPS. But the following coa (400 bp and $800 \mathrm{bp})$, spa (1100 bp and $1120 \mathrm{bp})$, aae (220 bp), and IcaD (100 bp) genes were present only in a hospital acquired MRCoPS. The PVL gene was absent in both community and hospital acquired MRCoPS isolates.

\section{Conclusion}

Hospital acquired coagulase positive staphylococci were highly significant resistant effects against oxacillin and intermediate effects against cefoxitin compared to community acquired coagulase positive staphylococci. All coagulase positive staphylococcus isolates were sensitive to sulfamethoxazole/trimethoprim and quinupristin, but they were resistant to penicillin only. Genotypically, all tested toxin genes showed variation between community and hospital depending on the gene size bands. This study stresses the vital would like for broad screening, precautionary, and educational methods to accomplish the cumulative MRSA prevalence rate. 


\section{Background}

The first isolation of methicillin-resistant coagulase-positive staphylococcus (MRCoPS) was in 1961. The second wave of epidemic MRCoPS was in 1980. MRCoPS is a major bacterial pathogen that causes a variety of infections in Saudi Arabia and worldwide [1-4]. In 2000, there were increases in the number of reports of community acquired (CA) and hospital acquired (HC) MRCoPS [5-7]. MRCoPS is part of the normal flora of the upper respiratory tract, or especially the nose and nasopharyngeal, thus frequently causing hospital and community-acquired infections. Methicillin resistance in staphylococci is caused by bacterial expression of the $m e c A$ gene that alters penicillin-binding protein (PBP-2) to PBP-2a resulting in loss of target affinity.

In the Saudi Arabia, only a few studies are performed to date to research the frequency of MRCoPS and documentation of the risk factors related to MRCoPS infection within the healthy and/or hospital patients. In 1991, the first report showed that Saudi and British strains differed in their sensitivity pattern to antibiotics [8]. In 1993, Haddad et al. study documented the first outbreak of MRCoPS in neonatal intensive care unit (ICU) in Riyadh and reported that overcapacity, inadequate space, and inadequate maintenance were implicated as the major risk factors [9].

The first epidemiological report on MRCoPS from the Saudi Arabia was in the year 1994 from the western region (Jeddah) [10]. MRCoPS covered about $7.5 \%$ of all coagulases positive staphylococcus isolates studied over three years, with $71 \%$ of them obtained from wound sites [10]. Alghaithy et al. [11] have examined the carrier status and antibiotic resistance among hospital and non-hospital personnel in Abha and isolated MRCoPS from $5.1 \%$ of the hospital and $18.3 \%$ from the non-hospital carriers. Nevertheless, $44 \%$ of the hospital carrier isolates revealed multiple resistance as contrasted to $8 \%$ of the non-hospital carriers. Moreover, multiple resistance was more frequent among inpatients (8\%) as contrasted to outpatients (1\%) [11]. Several authors $[12,13,14,15]$ have shown that the prevalence of MRCoPS at a tertiary care hospital is rising in the kingdom, and therefore management measures are required to be developed and efficiently utilized [16, 17].

It is important to distinguish between the isolates from CA-MRCoPS and HA-MRCoPS in the Saudi Arabia. The phenotypical and genotypical of MRCoPS isolates will help researchers to comprehend and supervise the rapidly modifying epidemiology of MRCoPS, and to build a standard from which to assess sequential developments in molecular characteristics of MRCoPS associated with diseases. But there are several obstacles with the use of a method based on the lack of healthcare risk factors in the Saudi Arabia. First, each CA- and HA-MRCoPS strains currently flow within the community. Second, supposed HA-MRCoPS strains area unit bit by bit changing into entrenched as medical building pathogens. The study aims were to indicate and prove associated with variation between nasal discharge isolates from CA- and HAMRCoPS in the central of the Saudi Arabia characteristically as phenotypically and genotypically.

\section{Method}

\section{Sample collection}


A total of 200 nasal swabs were collected between April 2017 to December 2018 from two different communities. First hospital samples $(n=83)$ included physicians $(n=7)$, nurses $(n=12)$, radiologists $(n=8)$, laboratory medical specialists $(n=8), \operatorname{ECHO}(n=1)$, medical residents $(n=1)$, hospital admins $(n=6)$, clinical nutrition $(n=1)$, internship students $(n=35)$ and medical research assistants $(n=4)$ at King Abdulaziz Medical City (KAMC), Riyadh, Saudi Arabia. Second community samples $(n=117)$, we concentrated on academic faculties $(n=10)$, admins $(n=36)$, and students $(n=71)$ at King Saud Bin Abdulaziz University for Health Sciences (KSAU-HS), Riyadh, Saudi Arabia. The exclusion for hospital were patients, and personnel who worked part-time at KAMC; for the community were students who were in direct contact with patients, and those with incomplete records were excluded from this study.

\section{Specimen collection and transport}

A dry polyester swab was inserted into the naris, parallel to the roof of the mouth, and left in situ for some seconds. Specimens from each nostril were obtained with an identical swab. The collected nasal swabs were transported to the lab research as soon as possible. If not were kept at $2-30^{\circ} \mathrm{C}$ until transported to the lab. If the process of collected nasal swabs could not be performed within $36 \mathrm{hr}$, they were stored in the refrigerator at $2-8^{\circ} \mathrm{C}$ for a maximum of five days. The collection of nasal swabs was daily during the working day for up to 3 months.

\section{Isolation and identification of coagulase-positive staphylococcus}

Initial screening and identification of CoPS isolates were performed according to the standard laboratory protocols. Briefly, the collected nasal swabs were streaked directly on mannitol salt agar (MSA), and S. aureus isolates were tested for methicillin resistance using a standard oxacillin salt agar screening plate procedure and cefoxitin susceptibility as indicated by the Clinical and Laboratory Standards Institute (CLSI) [18]. For confirmation, chromogenic agar was used for rapid MRSA screening since this agar had high sensitivity for MRCoPS (>98\%) [19]. Methicillin-resistant and methicillin-sensitive staphylococcus strains were included as controls. Confirmation of methicillin-resistance was done by inoculating a $10 \mathrm{~L}$ aliquot of a bacterial suspension with $3 \times 10^{6} \mathrm{CFU} / \mathrm{mL}$ (McFarland turbidity no. 1) on Mueller-Hinton agar (MHA) supplemented with calcium (50 mg/L), magnesium $(25 \mathrm{mg} / \mathrm{L})$, sodium chloride $(4 \%)$ and oxacillin $(4 \mathrm{~g} / \mathrm{mL})$. The growth of at least one well-defined colony on these plates incubated at $30^{\circ} \mathrm{C}$ for $48 \mathrm{hr}$ was suggestive of MRSA. The methicillin-resistance strain was confirmed by microdilution in Muller-Hinton broth supplemented with cations and sodium chloride, using a final inoculation of $7.5 \times 10^{4} \mathrm{CFU}$. MRSA was identified with a minimal inhibitory concentration (MIC) of oxacillin $>8 \mathrm{~g} / \mathrm{mL}$, and those with a MIC $<1 \mathrm{~g} / \mathrm{mL}$ were considered as methicillin-sensitive staphylococcus (MSSA). A MIC of oxacillin between $>1 \mathrm{~g} / \mathrm{mL}$ and $<8 \mathrm{~g} / \mathrm{mL}$ was defined as a methicillin-intermediate staphylococcus (MISA) [20].

\section{Antimicrobial susceptibility testing}

Antimicrobial susceptibility of isolated coagulase positive staphylococcus towards 7 antimicrobials was determined by the agar dilution method in Mueller-Hinton agar according to the Clinical and Laboratory Standard Institute (CLSI) guidelines [18] and the results were evaluated after incubation at $35^{\circ} \mathrm{C}$ for $24 \mathrm{hr}$. 
The discs were penicillin (P, $1 \mu \mathrm{g})$, cefoxitin (FOX, $30 \mu \mathrm{g}$ ), vancomycin (VA, $30 \mu \mathrm{g})$, clindamycin (CC, $2 \mu \mathrm{g})$, sulfamethoxazole/trimethoprim (SXT, $25 \mu \mathrm{g}$ ), rifampin (RA, $25 \mu \mathrm{g}$ ), and quinupristin (SYN, $15 \mu \mathrm{g}$ ). A fresh subculture of isolates was prepared on MSA and incubated at $37^{\circ} \mathrm{C}$ for $18-24 \mathrm{hr}$. With the help of a wire loop, 4-5 well-isolated colonies of comparable look were picked and transferred into the tube of sterile traditional saline. The clumping of cells was avoided by emulsifying the inoculum inside the tube. The inoculums were adjusted to $0.5 \mathrm{McF}$ arland (McFarland 0.5 equals approximately $10^{8} \mathrm{CFU} / \mathrm{mL}$ ). After adjusting the inoculum within $15 \mathrm{~min}$, a sterile cotton swab was swayback into the inoculum. The swab was patterned over the complete surface of the MHA plate, rotating the plate just about $60^{\circ}$ three times to make sure merging growth. Inoculation was completed by running the swab around the surface of the agar. Excess moisture on the agar surface could be absorbed before applying the antimicrobial discs. MSSA ATTC 25923, MSSA ATCC 229213, MRSA ATCC BAA1026, and Staphylococcus epidermidis ATCC 1228 were used as control strains.

\section{Genetic characterization of methicillin-resistant coagulase-positive staphylococcus}

\section{DNA extraction}

Ten microliters of overnight Lysogeny broth culture in a tube were centrifuged at $8000 \mathrm{rpm}$ for $10 \mathrm{~min}$ and the supernatant was discarded. The pellet was suspended in phosphate buffer saline using vortex then centrifuged again and the supernatant was discarded. Then the pellet was suspended in $2 \mathrm{~mL}$ of TE buffer and mixed by the vortex. A $500 \mathrm{~L}$ was transferred to $1.5 \mathrm{ml}$ Eppendorf and $50 \mathrm{~L}$ of SDS (10\%) and 5 $\mathrm{L}$ of proteinase $\mathrm{K}$ were added and left in the incubator for $1.5 \mathrm{hr}$ at $37^{\circ} \mathrm{C}$. An equal volume of $(5 \mathrm{~L})$ phenol, chloroform, isoamyl mixture was added, vortexed for $1 \mathrm{~min}$, centrifuged for $4 \mathrm{~min}$, and the aqueous supernatant containing DNA was transferred to another tube. A fifty-five $L$ of $3 \mathrm{M}$ sodium acetate and double volume of cold alcohol (100\%) were added and mixed gently 2-3 times and centrifuged for $10 \mathrm{~min}$. the supernatant was removed and the pellet was washed by mixing gently with $1 \mathrm{~mL}$ of $70 \%$ alcohol and centrifuged for $1 \mathrm{~min}$. The supernatant was removed, and the pellet was left to dry then suspended in $10 \mathrm{~L}$ of TE buffer and incubated for $30 \mathrm{~min}$ at $55^{\circ} \mathrm{C}$ and stored at $-20^{\circ} \mathrm{C}$ [21].

\section{Detection of the coa and spa genes}

The identified CoPS strains subject to a polymerase chain reaction (PCR) for coa gene detection, using the following primers: forward (5'-CGA GAC CAA GAT TCA ACA AG-3') and reverse (5'-AAA GAA AAC CAC TCA CAT CA-3'), which design to amplify the 3 ' ends hypervariable region containing 81-base pair (bp) tandem repeats of coa gene. The amplification reaction consisted of associate degree initial denaturation step at $94^{\circ} \mathrm{C}$ for $5 \mathrm{~min}$, followed by thirty cycles of denaturation at $95^{\circ} \mathrm{C}$ for $30 \mathrm{sec}$, tempering at $55^{\circ} \mathrm{C}$ for $45 \mathrm{sec}$, extension at $72^{\circ} \mathrm{C}$ for $2 \mathrm{~min}$, followed by a final extension at $72^{\circ} \mathrm{C}$ for $7 \mathrm{~min}$ [22]. The tested CoPS strains focus on PCR for spa gene detection using the following primers: forward (5'-ATC TGG TGG CGT AAC ACC TG-3'), and reverse (5'-CGC TGC ACC TAA CGC TAA TG-3') which scheme to amplify the polymorphic region that contains a variable number of $24 \mathrm{bp}$ tandem repeats of the spa gene coding for protein $\mathrm{A}$. Amplification reaction consisted of associate degree initial denaturation step at $94^{\circ} \mathrm{C}$ for 4 min, followed by thirty-five cycles of denaturation at $94^{\circ} \mathrm{C}$ for one min, annealing at $56^{\circ} \mathrm{C}$ for one min, extension at $72^{\circ} \mathrm{C}$ 
for $3 \mathrm{~min}$, followed by a final extension at $72^{\circ} \mathrm{C}$ for $5 \mathrm{~min}$ [23]. The PCR product and restriction digest fragments were detected by electrophoresis in $2 \%$ agarose gel. The pictures were pictured and analyzed in Gel Doc (BIORAD).

\section{Detection of the mecA, SCCmecll, SCCmecVla, and SCCmecVlb genes}

All MRCoP isolates were tested for confirmation of the presence of the $310 \mathrm{bp}$ PCR product of the mecA gene, using the following primers: forward (5'-TGG CTA TCG TGT CAC AATCG-3') and reverse (5'-CTG GAA CTT GTT GAG CAG AG-3'). The amplification reaction was carried out in $25 \mathrm{~L}$ volumes, under the following conditions: initial denaturation at $92^{\circ} \mathrm{C}$ for 5 min, followed by 35 cycles of denaturation at $95^{\circ} \mathrm{C}$ for $30 \mathrm{sec}$, annealing at $56^{\circ} \mathrm{C}$ for 30 seconds, and extension at $72^{\circ} \mathrm{C}$ for $30 \mathrm{sec}$, followed by a final extension at $72^{\circ} \mathrm{C}$ for $3 \mathrm{~min}$ [24]. Identification of the SCCmec complex was performed by a PCR screen for SCCmecll (287 bp) and SCCmelVa (776 bp) and SCCmecIVb (1000 bp) using the DNA extract prepared above as a template. DNA samples were tested for the presence of the SCCmec complex, using the following primers: for SCCme // gene, forward 5'-CAA AAG GAC TGG ACT GGA GTC CAA A-3' and reverse 5'-CAA GTG AAT TGA AAC CGC CT-3'; for SCCmec/Va gene, forward 5'-TTT GAA TGC CCT CCA TGA ATA AAA T-3' and reverse 5'-AGA AAA GAT AGA AGT TCG AAA GA-3'; for SCCmeclVb gene, forward 5'-AGT ACA TTT TAT CTT TGC GTA-3'and reverse 5'-AGT CAT CTT CAA TAT CGA GAA AGT A-3'. Samples were heated for $1 \mathrm{~min}$ at $95^{\circ} \mathrm{C}, 30 \mathrm{cycles}$ of $\left[30 \mathrm{sec}\right.$ at $94^{\circ} \mathrm{C}, 60 \mathrm{sec}$ at $50^{\circ} \mathrm{C}$ and $120 \mathrm{sec}$ at $72^{\circ} \mathrm{C}$, and $2 \mathrm{~min}$ at $72^{\circ} \mathrm{C}$ [25]. The PCR product and restriction digest fragments were detected by electrophoresis in $2 \%$ agarose gel. The pictures were pictured and analyzed in Gel Doc (BIORAD).

\section{Detection of the aae, aap, emb, IcaD, and PVL genes}

DNA samples were tested for the presence of the 110 to $220 \mathrm{bp} \mathrm{PCR} \mathrm{product} \mathrm{of} \mathrm{aae} \mathrm{gene,} \mathrm{using} \mathrm{the}$ following primers: forward 5'-AAC AAA TTG ATA AAG CAA CG-3' and reverse 5'-GTT GTC TTT CCT TTA GTG TC-3'. Samples were heated at $95^{\circ} \mathrm{C}$ for $10 \mathrm{~min}$ before cycling for 45 cycles of $95^{\circ} \mathrm{C}$ for $10 \mathrm{sec}, 5^{\circ} \mathrm{C}$ for $20 \mathrm{sec}$, and $72^{\circ} \mathrm{C}$ for $25 \mathrm{sec}$ [26]. The aap gene was detected using PCR with a specific primer: forward 5'-TCA CTAAAC AAC CTG TTG ACG AA-3' and reverse 5'-AAT TGA TTT TTA TTA TCT GTT GAA TGC-3'. Samples were heated at $94^{\circ} \mathrm{C}$ for $4 \mathrm{~min}$, followed by 25 cycles of $94^{\circ} \mathrm{C}$ for $30 \mathrm{sec}, 55^{\circ} \mathrm{C}$ for $30 \mathrm{sec}, 72^{\circ} \mathrm{C}$ for $1 \mathrm{~min}$, and $72^{\circ} \mathrm{C}$ for $5 \mathrm{~min}$ [27]. All isolated MRSA were tested for the presence of the $455 \mathrm{bp} \mathrm{PCR}$ product of the embp gene, using the following primers: forward 5'-AGC GGT ACA AAT GTC AAT ATC-3'and reverse 5'-AGA AGT GCT CTA GCA TCA TCC-3'. Amplification reaction consisted of an initial denaturation step $\left(96^{\circ} \mathrm{C}\right.$ for $\left.2 \mathrm{~min}\right), 40$ amplification cycles of $94^{\circ} \mathrm{C}$ for $1 \mathrm{~min}, 55^{\circ} \mathrm{C}$ for $30 \mathrm{sec}$ and $72^{\circ} \mathrm{C}$ for $1 \mathrm{~min}$, with a final 10-min extension step at $72^{\circ} \mathrm{C}$ [28]. DNA samples were tested for the presence of the $188 \mathrm{bp} \mathrm{PCR}$ product of IcaD gene, using the following primers: forward 5'-ATG GTC AAG CCC AGA CAG AG-3'and reverse $5^{\prime}$-CGT GTT TTC AAC ATT TAA TGC AA-3'. Samples were heated at $94^{\circ} \mathrm{C}$ for $5 \mathrm{~min}$, followed by 50 cycles at $94^{\circ} \mathrm{C}$ for $30 \mathrm{sec}, 55.5^{\circ} \mathrm{C}$ for $30 \mathrm{sec}, 72^{\circ} \mathrm{C}$ for $30 \mathrm{sec}$, and $72^{\circ} \mathrm{C}$ for $1 \mathrm{~min}$ after the conclusion of the 50 cycles [29]. The primer sequence for the PVL gene was described previously by McClure et al. [30]. The primer was used for the co-amplification of $P V L$ genes: forward 5'-ATC ATT AGG TAA AAT GTC TGG ACA TGA TCC A- 3' and reverse 5'-GCA TCA ACT GTA TTG GAT AGC AAA AGC- 3' procedure as indicated by the 
CLSI $[18,30]$. Amplification reaction consisted of an initial denaturation step at $94^{\circ} \mathrm{C}$ for 3 min followed by 30 cycles of the following steps: denaturation at $94^{\circ} \mathrm{C}$ for $30 \mathrm{sec}$, annealing at $55^{\circ} \mathrm{C}$ for $30 \mathrm{sec}$, extension at $72^{\circ} \mathrm{C}$ for $1 \mathrm{~min}$, and a final extension at $72^{\circ} \mathrm{C}$ for $5 \mathrm{~min}$ [30]. The PCR products and restriction digest fragments were identified by electrophoresis in $2 \%$ agarose gel. The images were visualized and analyzed in Gel Doc (BIORAD).

\section{Statistical analysis}

Statistical analysis was performed with SPSS (v.22.0) statistics software. The variation between Healthy and healthcare communities by several variables. Observed differences were assessed for statistical significance by chi-square. A significant difference was statistically accounted for at a p-value of $<0.05$.

\section{Ethical considerations}

The Institutional Review Board (IRB) at King Abdullah International Medical Research Centre (KAIMRC) granted permission to conduct the project after reviewing the ethical aspects of the proposal (File\#3190/2015).

\section{Result}

In total 200 nasal swabs were collected for this study. Where $58.5 \%$ of collected nasal swabs were from CA infection and $41.7 \%$ of collected nasal swabs were from HA infection.

\section{Isolation of Staphylococcus species using mannitol salt agar (Table 1)}

In total 200 nasal swabs, 24 (12\%) of them showed growth of CoPS only. Where $11.1 \%$ of isolated CoPS were from CA infection and 13.3\% from HA infection. Sixty (30\%) coagulase-negative staphylococci (CoNS) were isolated out of the total number of collected nasal swabs. The only factor significantly among CA infection was the nasal swabs growth of both CoPS and CoNS $(77.8 \%)(p$-value $=0.007)$ compared to HA infection $21.7 \%$. Whereas the only factor significantly among HA was the nasal swabs growth of only CoNS $(57.8 \%)$ ( $p$-value $=0.006$ ) compared to CA $(10.3 \%)$. Only $1.2 \%$ of HA nasal swabs showed bacterial growth other than staphylococcus. Whereas $3 \%$ of nasal swabs showed no bacterial growth: $0.9 \%$ from $\mathrm{CA}$ and $6 \%$ from $\mathrm{HA}$, respectively. In summary, a total of 133 CoPS were isolated from mannitol salt agar, 104 CoPS from CA, and 29 from HA. 
Table 1

Isolation of microorganisms by using mannitol salt agar.

\begin{tabular}{|c|c|c|c|c|c|}
\hline & $\begin{array}{l}\text { Number } \\
\text { (n) }\end{array}$ & $\begin{array}{l}\text { Percentage } \\
\text { (\%) }\end{array}$ & $\begin{array}{l}\text { Total } \\
(\mathrm{CA}+\mathrm{HA}) \\
{[n(\%)]}\end{array}$ & $\begin{array}{l}\text { Proportion } \\
\text { (n/Number of } \\
\text { participants) }\end{array}$ & $p-$ \\
\hline $\begin{array}{l}\text { Number of } \\
\text { participants } \\
\text { CA } \\
\text { HA }\end{array}$ & $\begin{array}{l}117 \\
83\end{array}$ & $\begin{array}{l}58.5 \\
41.7\end{array}$ & $200(100)$ & - & 0.010 \\
\hline $\begin{array}{l}\text { CoPS } \\
\text { CA } \\
\text { HA }\end{array}$ & $\begin{array}{l}13 \\
11\end{array}$ & $\begin{array}{l}11.1 \\
13.3\end{array}$ & $24(12)$ & $\begin{array}{l}0.111 \\
0.133\end{array}$ & 0.737 \\
\hline $\begin{array}{l}\text { CoNS } \\
\text { CA } \\
\text { HA }\end{array}$ & $\begin{array}{l}12 \\
48\end{array}$ & $\begin{array}{l}10.3 \\
57.8\end{array}$ & $60(30)$ & $\begin{array}{l}0.103 \\
0.578\end{array}$ & 0.006 \\
\hline $\begin{array}{l}\text { CoPS and CoNS } \\
\text { CA } \\
\text { HA }\end{array}$ & $\begin{array}{l}91 \\
18\end{array}$ & $\begin{array}{l}77.8 \\
21.7\end{array}$ & $\begin{array}{l}109 \\
(54.5)\end{array}$ & $\begin{array}{l}0.778 \\
0.217\end{array}$ & 0.007 \\
\hline $\begin{array}{l}\text { Other bacteria } \\
\text { CA } \\
\text { HA }\end{array}$ & $\begin{array}{l}0 \\
1\end{array}$ & $\begin{array}{l}0.0 \\
1.2\end{array}$ & $1(0.5)$ & $\begin{array}{l}0 \\
0.012\end{array}$ & 0.344 \\
\hline $\begin{array}{l}\text { No bacterial growth } \\
\text { CA } \\
\text { HA }\end{array}$ & $\begin{array}{l}1 \\
5\end{array}$ & $\begin{array}{l}0.9 \\
6.0\end{array}$ & $6(3)$ & $\begin{array}{l}0.009 \\
0.060\end{array}$ & 0.180 \\
\hline
\end{tabular}

Antimicrobial susceptibility test and Oxacillin E-test of isolated coagulase-positive staphylococcus (Table 2)

The oxacillin E-test was used against the 133 CoPS isolates. Thirty (22.6\%) out of 133 CoPS isolates were resistant to oxacillin. The resistance to oxacillin was highly significant in HA-CoPS isolates $(34.5 \%)$ than in CA-CoPS isolates $(19.2 \%$ ) ( $p$-value $=0.009$ ). Whereas $10.5 \%$ showed intermediate effects to oxacillin, but it was not statistically significant $(p$-value $=0.464)$. Eighty-nine out of 133 showed sensitivity results to oxacillin, but it was not statistically significant ( $p$-value $=0.182$ ). All coagulase-positive staphylococcus isolates in our study were susceptible to sulfamethoxazole/trimethoprim and quinupristin but resistant to 
penicillin. In CA-CoPS, the antimicrobial susceptibility test showed resistance against cefoxitin (28.9\%), clindamycin (9.5\%), and rifampin (4.8\%). The test also showed intermediate results against cefoxitin (14.4\%), vancomycin (4.8\%), and clindamycin (9.5\%). In addition, statistical studies showed that CA-CoPS isolates were highly significant susceptible to cefoxitin ( $p$-value $=0.003)$ and vancomycin $(p$-value $=$ 0.008). For HA-CoPS isolates, the antimicrobial susceptibility test showed resistance against only cefoxitin (38.5\%). The test also showed intermediate results against cefoxitin (30.8\%) and vancomycin (46.2\%). The three factors that statistically significant for HA-CoPS isolates were susceptibility to clindamycin $(p$-value $=0.011)$, and intermediate effects against both cefoxitin $(p$-value $=0.009)$ and against vancomycin ( $p$-value $=0.005)$. 
Table 2

Antimicrobial susceptibility test and Oxacillin E-test of isolated coagulase-positive staphylococcus.

\begin{tabular}{|c|c|c|c|c|c|c|c|c|c|}
\hline \multirow{2}{*}{$\begin{array}{l}\text { Variables } \\
\text { CA-SA }(n= \\
104) \\
\text { HA-SA }(n= \\
29)\end{array}$} & \multicolumn{3}{|c|}{ Number [n (\%)] } & \multicolumn{3}{|c|}{$\begin{array}{l}\text { Proportion (number/Total } \\
\text { Number) }\end{array}$} & \multicolumn{3}{|c|}{$p$-Value } \\
\hline & $\mathbf{R}$ & $\mathbf{I}$ & S & $\mathbf{R}$ & $\mathbf{I}$ & S & $\mathbf{R}$ & I & S \\
\hline \multicolumn{10}{|c|}{ E-Test Method (MIC) } \\
\hline Oxacillin & \multirow{2}{*}{$\begin{array}{l}20 \\
(19.2) \\
10 \\
(34.5)\end{array}$} & $\begin{array}{l}12 \\
(11.5)\end{array}$ & $\begin{array}{l}72 \\
(69.2)\end{array}$ & \multirow{2}{*}{0.345} & \multirow{2}{*}{0.069} & \multirow{2}{*}{0.586} & \multirow[t]{2}{*}{0.009} & \multirow[t]{2}{*}{0.464} & \multirow[t]{2}{*}{0.182} \\
\hline $\begin{array}{l}\text { CA-CoPS } \\
\text { HA-CoPS }\end{array}$ & & $2(6.9)$ & $\begin{array}{l}17 \\
(58.6)\end{array}$ & & & & & & \\
\hline \multicolumn{10}{|c|}{ Disc Diffusion Method } \\
\hline \multicolumn{10}{|c|}{ 1) $\beta$-Lactam Antibiotics } \\
\hline $\begin{array}{l}\text { FOX30 } \\
\text { CA-CoPS } \\
\text { HA-CoPS }\end{array}$ & $\begin{array}{l}30 \\
(28.9) \\
11 \\
(38.5)\end{array}$ & $\begin{array}{l}15 \\
(14.4) \\
9 \\
(30.8)\end{array}$ & $\begin{array}{l}59 \\
(56.7) \\
9(31)\end{array}$ & $\begin{array}{l}0.288 \\
0.379\end{array}$ & $\begin{array}{l}0.144 \\
0.818\end{array}$ & $\begin{array}{l}0.567 \\
0.310\end{array}$ & 0.165 & 0.009 & 0.003 \\
\hline $\begin{array}{l}\text { P10 } \\
\text { CA-CoPS } \\
\text { HA-CoPS }\end{array}$ & $\begin{array}{l}104 \\
(100) \\
29 \\
(100)\end{array}$ & $\begin{array}{l}0(0) \\
0(0)\end{array}$ & $\begin{array}{l}0(0) \\
0(0)\end{array}$ & $\begin{array}{l}1 \\
1\end{array}$ & $\begin{array}{l}0 \\
0\end{array}$ & $\begin{array}{l}0 \\
0\end{array}$ & ns & ns & ns \\
\hline \multicolumn{10}{|c|}{ 2) Non- $\beta$-Lactam Antibiotics } \\
\hline $\begin{array}{l}\text { VA30 } \\
\text { CA-CoPS } \\
\text { HA-CoPS }\end{array}$ & $0(0)$ & $\begin{array}{l}13 \\
(46.2)\end{array}$ & $\begin{array}{l}99 \\
(95.2) \\
16 \\
(55.2)\end{array}$ & 0 & 0.462 & $\begin{array}{l}0.952 \\
0.552\end{array}$ & ns & 0.005 & 0.008 \\
\hline $\begin{array}{l}\text { CC2 } \\
\text { CA-CoPS } \\
\text { HA-CoPS }\end{array}$ & $\begin{array}{l}10 \\
(9.5) \\
0(0)\end{array}$ & $\begin{array}{l}10 \\
(9.5) \\
0(0)\end{array}$ & $\begin{array}{l}84(81) \\
29 \\
(100)\end{array}$ & $\begin{array}{l}0.096 \\
0\end{array}$ & $\begin{array}{l}0.096 \\
0\end{array}$ & $\begin{array}{l}0.808 \\
1\end{array}$ & 0.163 & 0.163 & 0.011 \\
\hline $\begin{array}{l}\text { SXT25 } \\
\text { CA-CoPS } \\
\text { HA-CoPS }\end{array}$ & $\begin{array}{l}0(0) \\
0(0)\end{array}$ & $\begin{array}{l}0(0) \\
0(0)\end{array}$ & $\begin{array}{l}104 \\
(100) \\
29 \\
(100)\end{array}$ & $\begin{array}{l}0 \\
0\end{array}$ & $\begin{array}{l}0 \\
0\end{array}$ & $\begin{array}{l}1 \\
1\end{array}$ & ns & ns & ns \\
\hline
\end{tabular}

Penicillin $10 \mu \mathrm{g}$ (P10); Cefoxitin $30 \mu \mathrm{g}$ (FOX30); Vancomycin $30 \mu \mathrm{g}$ (VA30); Clindamycin $2 \mu \mathrm{g}$ (CC2); Sulfmeth/Trimeth $25 \mu \mathrm{g}$ (SXT25); Rifampin $25 \mu \mathrm{g}$ (RA25); Quinupristin $15 \mu \mathrm{g}$ (SYN15). 


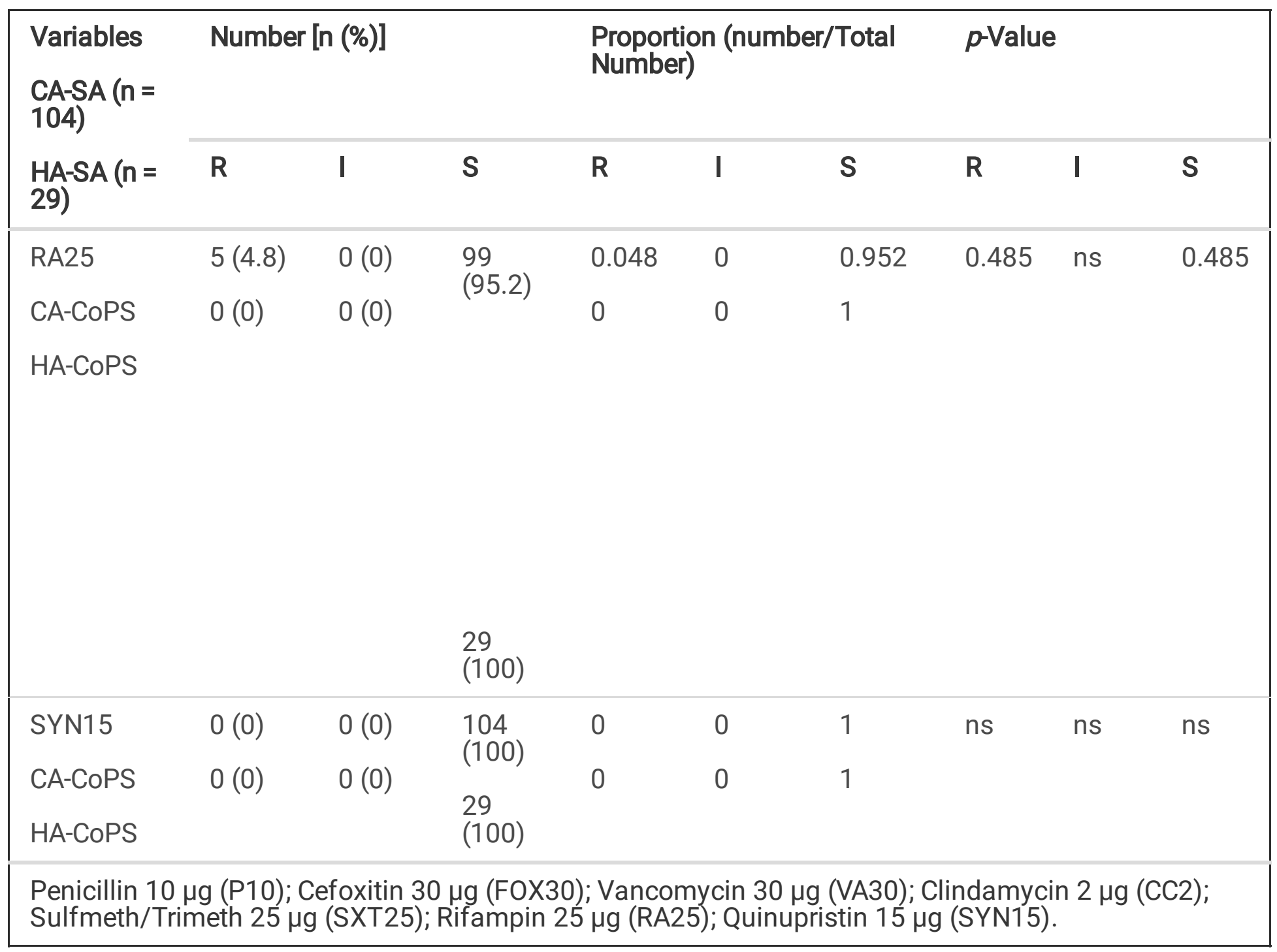

Detect mec genes for isolated methicillin-resistant coagulase-positive staphylococcus using PCR (Table 3)

Genotypically, all MRCoPS isolates showed no bands for SCCmecll, SCCmecVla, and SCCmecVIb genes. In a total of 30 CA-MRCoPS, 25 (83.3\%) showed mecA gene band (300 bp). But 9 (81.8\%) mecA gene bands (300 bp) were observed in a total of 11 HA-MRCoPS. In total 34 (82.9\%) out of phenotypically confirmed 43 MRCoPS isolates showed mecA gene bands. They were considered and confirmed as MRCoPS and used for further genotypic testing. 
Table 3

Detect $m e c$ genes for suspected isolated methicillin resistant coagulase-positive staphylococcus using PCR.

\begin{tabular}{|llll|}
\hline & CA-MRSA $(\mathbf{n}=\mathbf{3 0})$ & HA-MRSA $(\mathbf{n}=\mathbf{1 1})$ & Total $(\mathbf{n}=\mathbf{4 1})$ \\
\hline mecA gene (300 bp) & $25(83.3)$ & $9(81.8)$ & $34(82.9)$ \\
\hline sCCmecll gene & $0(0)$ & $0(0)$ & $0(0)$ \\
\hline sCCmecVla gene & $0(0)$ & $0(0)$ & $0(0)$ \\
\hline sCCmecVlb gene & $25(83.3)$ & $9(81.8)$ & $34(82.9)$ \\
\hline
\end{tabular}

Typing coa and spa genes for isolated methicillin-resistant coagulase-positive staphylococcus using PCR (Table 4)

Both CA- and HA-MRCoPS showed different size bands for the coa and spa genes. For coa gene, CAMRCoPS showed three different coa gene bands: $81 \mathrm{bp}(100 \%), 120 \mathrm{bp}(4 \%)$ and $720 \mathrm{bp}(8 \%)$. Whereas HA-MRCoPS showed presence five different coa gene bands: 81 bp (100\%), 120 bp (44.4\%), 400 bp (22.2\%), $720 \mathrm{bp}(22.2 \%)$ and $800 \mathrm{bp}(33.3 \%)$. For spa gene, CA-MRCoPS showed only one band size of $1100 \mathrm{bp}(64 \%)$. Whereas HA-MRSA showed three different bands size: 1020 bp (11.1\%), 1100 bp (33.3\%), and $1120 \mathrm{bp}(11.1 \%)$.

Table 4

Detecting patterns of coa and spa genes from isolated methicillin resistant coagulase-positive staphylococcus using PCR.

\begin{tabular}{|c|c|c|c|c|c|c|c|c|}
\hline & \multicolumn{4}{|c|}{ coa gene (n (\%)) } & \multicolumn{4}{|c|}{ spa gene (n (\%)) } \\
\hline & $81 \mathrm{bp}$ & $120 \mathrm{bp}$ & $400 \mathrm{bp}$ & 720 bp & 800 bp & $\begin{array}{l}1020 \\
\text { bp }\end{array}$ & $\begin{array}{l}1100 \\
\text { bp }\end{array}$ & $\begin{array}{l}1120 \\
\text { bp }\end{array}$ \\
\hline $\begin{array}{l}\text { CA-MRSA }(n= \\
25)\end{array}$ & $\begin{array}{l}25 \\
(100)\end{array}$ & $1(4)$ & $0(0)$ & $2(8)$ & $0(0)$ & $0(0)$ & $16(64)$ & $0(0)$ \\
\hline $\begin{array}{l}\text { HA-MRSA ( } n= \\
\text { 9) }\end{array}$ & $9(100)$ & $\begin{array}{l}4 \\
(44.4)\end{array}$ & $\begin{array}{l}2 \\
(22.2)\end{array}$ & $\begin{array}{l}2 \\
(22.2)\end{array}$ & $\begin{array}{l}3 \\
(33.3)\end{array}$ & $\begin{array}{l}1 \\
(11.1)\end{array}$ & $\begin{array}{l}3 \\
(33.3)\end{array}$ & $\begin{array}{l}1 \\
(11.1)\end{array}$ \\
\hline
\end{tabular}

Detecting other genes for isolated methicillin-resistant coagulase-positive staphylococcus using PCR (Table 5)

All MRCoPS isolates showed no bands for the $P V L$ gene. Whereas, for aae gene, a different band size observed in CA-MRCoPS compared to HA-MRCoPS: 220 bp (24\%), and 110 bp (22.2\%), respectively. While five bands of aap gene showed only in CA-MRCoPS of different sizes (180 bp, $200 \mathrm{bp}, 460 \mathrm{bp}$, and 480 bp). For the emb gene, CA-MRCoPS showed two different bands size: $50 \mathrm{bp}(100 \%)$ and $480 \mathrm{bp}(24 \%)$; whereas HA-MRCoPS showed only one band size: $50 \mathrm{bp}$ (100\%). For the IcaD gene, CA-MRCoPS showed only one band size: $200 \mathrm{bp}(44.8 \%)$; whereas HA-MRCoPS showed two different bands size: $100 \mathrm{bp}$ (11.1\%) and 200 bp (33.3\%), respectively. 
Table 5

Detecting patterns of other genes from isolated methicillin resistant coagulase-positive staphylococcus using PCR.

\begin{tabular}{|c|c|c|c|c|c|c|c|c|c|c|c|c|}
\hline & aae & & aap & ne & & & & $e m b \mathrm{~g}$ & & $I c a D g$ & & Luk- \\
\hline & $\begin{array}{l}110 \\
b p\end{array}$ & $\begin{array}{l}220 \\
\text { bp }\end{array}$ & $\begin{array}{l}180 \\
\text { bp }\end{array}$ & $\begin{array}{l}200 \\
\text { bp }\end{array}$ & $\begin{array}{l}300 \\
\mathrm{bp}\end{array}$ & $\begin{array}{l}460 \\
\text { bp }\end{array}$ & $\begin{array}{l}480 \\
\text { bp }\end{array}$ & $\begin{array}{l}50 \\
\text { bp }\end{array}$ & $\begin{array}{l}480 \\
\mathrm{bp}\end{array}$ & $\begin{array}{l}100 \\
b p\end{array}$ & $\begin{array}{l}200 \\
\text { bp }\end{array}$ & $\begin{array}{l}433 \\
\text { bp }\end{array}$ \\
\hline $\begin{array}{l}\text { CA- } \\
\text { MRSA } \\
(n= \\
25)\end{array}$ & $\begin{array}{l}0 \\
(0)\end{array}$ & $\begin{array}{l}6 \\
(24)\end{array}$ & $\begin{array}{l}6 \\
(24)\end{array}$ & $\begin{array}{l}6 \\
(24)\end{array}$ & $\begin{array}{l}6 \\
(24)\end{array}$ & $\begin{array}{l}6 \\
(24)\end{array}$ & $\begin{array}{l}6 \\
(24)\end{array}$ & $\begin{array}{l}25 \\
(100)\end{array}$ & $\begin{array}{l}6 \\
(24)\end{array}$ & $0(0)$ & $\begin{array}{l}13 \\
(44.8)\end{array}$ & $0(0)$ \\
\hline $\begin{array}{l}\text { HA- } \\
\text { MRSA } \\
(n=9)\end{array}$ & $\begin{array}{l}2 \\
(22)\end{array}$ & $\begin{array}{l}0 \\
(0)\end{array}$ & $\begin{array}{l}0 \\
(0)\end{array}$ & $\begin{array}{l}0 \\
(0)\end{array}$ & $\begin{array}{l}0 \\
(0)\end{array}$ & $\begin{array}{l}0 \\
(0)\end{array}$ & $\begin{array}{l}0 \\
(0)\end{array}$ & $\begin{array}{l}9 \\
(100)\end{array}$ & $\begin{array}{l}0 \\
(0)\end{array}$ & $\begin{array}{l}1 \\
(11.1)\end{array}$ & $\begin{array}{l}3 \\
(33.3)\end{array}$ & $0(0)$ \\
\hline
\end{tabular}

\section{Discussion}

MRCoPS is still an important health problem in all counties because it is transmissible and difficult to eliminate and treat. The variation between HA- and CA-MRCoPS has been used to monitor decisions about realistic therapy.

\section{Prevalence of CA-MRCoPS and HA-MRCoPS}

Al-Hamad et al. [31] study showed that CA-MRCoPS isolation increased steadily from $23 \%$ in 2006 to $60 \%$ in 2015, exceeding the rate of isolation of HA-MRCoPS in the Kingdom of Saudi Arabia. Other studies related to the prevalence of MRCoPS in the central region of the Kingdom of Saudi Arabia from 2017 to 2019 were selected according to the selection criteria in comparison with our study, two reported data from the community settings and five from hospital settings. In this study a total of 133 CoPS were isolated from nasal swabs of participants: 104 were from CA and 29 from HA infections. In HA infections, the prevalence of methicillin-resistance among CoPS was $21.4 \%$ nearly similar reports in the central regions of Saudi Arabia (2013 to 2020), such as $28 \%$ by Sirkhazi et al. [32], 24\% by Naeem et al. [33] and $22 \%$ by Shady et al. [34] and Alrabiah et al. [12]; but it was higher than Albarrag et al [35] study (9\%) and lower than Abujhesha et al. [36] study (43.4\%). Whereas in CA infections, the prevalence of MRCoPS was $10.8 \%$ higher than similar studies, such as Albusayes et al. [37] study was $3.3 \%$ and Alaklobi et al. [13] study was $4.6 \%$ prevalence.

\section{Antibiotic susceptibility test}

The oxacillin E-test showed highly significant resistance in HA-CoPS isolates (34.5\%) than in CA-CoPS isolates $(19.2 \%)$ ( $p$-value $=0.009)$. Whereas $10.5 \%$ showed intermediate effects to oxacillin, but it was not statistically significant ( $p$-value= 0.464$)$. Eighty-nine out of 133 showed sensitivity results to oxacillin, but it was not statistically significant $(p$-value $=0.182)$. In our study, the overall susceptibility of CA-CoPS 
isolates to the various antibiotics tested was: cefoxitin (56.7\%), vancomycin (95.2\%), clindamycin (81\%), rifampin (95.2\%), and quinupristin (100\%), respectively. Accordingly, the most effective antibiotic against CA-CoPS is quinupristin followed by vancomycin and rifampin then clindamycin. Our results for CA-CoPS were consistent with the previous studies $[38,39]$. HA-CoPS isolates, the overall susceptibility to the various antibiotics tested was: cefoxitin (31\%), vancomycin (55.2\%), clindamycin (100\%), sulfamethoxazole/trimethoprim (100\%), rifampin (100\%), and quinupristin (100\%), respectively. Bai et al. [40] and Shariati et al. [41] studies showed similar results. Accordingly, clindamycin, sulfamethoxazole/trimethoprim, rifampin, and quinupristin seem to be more effective against HA-CoPS. Like other studies, our findings also suggested that quinupristin is the most effective antibiotic against CA-CoPS and HA-CoPS isolates $[41,42]$. On the other hand, the intermediate effects of both cefoxitin and vancomycin were highly significant in HA-CoPS isolates compared with CA-CoPS isolates ( $p$-value $=0.009$ and 0.005$)$. The overall intermediate effects of CA-CoPS isolate to the various antibiotics tested was: cefoxitin (30.8\%), and vancomycin (46.2\%), respectively. In HA-CoPS isolates, the overall intermediate effects to the various antibiotics tested were: cefoxitin (14.4\%), vancomycin (4.8\%), and clindamycin (9.5\%), respectively. No intermediate effects showed against clindamycin in CA-CoPS isolates. Whereas the following antibiotics showed no intermediate effects against both CA-CoPS and HA-CoPS isolates were penicillin, sulfamethoxazole/trimethoprim, rifampin, and quinupristin. In several places like the United State, Africa, Middle East, and southeast Asia have successively discovered multiple intermediate CoPS against several tested antibiotics such as vancomycin $[43,44,45]$.

\section{Genotypic characterization of CA-MRCoPS and HA-MRCoPS}

Most of our tested genes showed the presence of more than one band. Several studies confirmed similar results such as Omar et al. [46], Goh et al. [47], Saei et al. [48], and Frenay et al. [49]. The explanation for the existence of more than one band was due to the presence of more than one allele's form. This polymorphic gene might be due to removal or supplement transformations by which a slice of the $3^{\prime}$ end area of the gene is erased or several nucleotides are implanted and therefore causes a modification in the gene $[46,47,48]$. Another explanation for the gene polymorphism is due to containing several base pair repeats, whose number and sequence differ among strains as seen with the X-region for the spa gene [46, 49]. Regarding the SCCmectypes, it was spotted that the type IVb was abundant in CA-and HA-MRCoPS isolates $(83.3 \%, 81.8 \%)$, while the type II and Vla were not spotted. Previous studies showed that HAMRCoPS strains carry SCCmec types I and II, whereas CA-MRCoPS strains carry SCCmec IV and V[50, 51, 52]. An extensive variety of surface proteins with adhesive properties developments the ability of MRCoPS to stick to different surfaces [53]. The autolysin/adhesin aae and aap intervene the early adhesion through hydrophobic connections [54]. Almost at the same time, extracellular matrix-binding protein $(e m b p)$ can precisely impasse to collagen, fibrinogen, and fibronectin respectively [55, 56, 57]. Additionally, aap and aae proteins bind non-specifically to fibrinogen, and fibronectin [58, 59]. Many MRCoPS isolates transport the IcaD operon that converts proteins elaborated in the creation of the polysaccharide intercellular adhesin (PIA), which links the bacteria cells in the biofilm [60,61]. PIA together with embp, aae, and aap is accountable for the intercellular adhesion and accretion, permitting biofilm development $[62,63,64]$. Our study showed variation in the presence of the above toxin gene proteins in CA-MRCoPS 
and HA-MRCoPS. The following coa (81 bp) and embp (50 bp) genes were present in similar prevalence among CA- MRCoPS and HA-MRCoPS (100\%). The following embp (480 bp), aap (180 bp, 200 bp, 300 bp, $460 \mathrm{bp}$, and $480 \mathrm{bp}$ ), and aae (110 bp) genes were present only in CA-MRCoPS, 24\%, 24\%, and 22.2\%, respectively. The following coa (400 bp and $800 \mathrm{bp}$ ), spa (1100 bp and $1120 \mathrm{bp}$ ), aae (220 bp) and IcaD (100 bp) genes were present only in HA-MRCoPS, $22.2 \%$ and $33.3 \%, 11.1 \%$ and $11.1 \%, 24 \%$, and $11.1 \%$, respectively. The following coa genes (120 bp and $720 \mathrm{bp}$ ) were present in higher prevalence among HAMRCoPS than in CA-MRCoPS, $44 \%$ vs $4 \%$ and $22.2 \%$ vs $8 \%$, respectively. An additional unique genetic feature of CA-MRCoPS is that a high percentage of strains convey genes for $P V L$, which is mostly inattentive from HA-MRCoPS strains $[65,66,67]$. Therefore, $P V L$ is expected to be answerable for the boosted pathogenic CA-MRCoPS strains. Our study showed that the PVL gene was negative not just in HA-MRCoPS but also in CA-MRCoPS isolates. The absence of PVL gene results in HA-MRCoPS were consistently recorded in Iraq [68], Poland [69], and Portugal [70].

\section{Conclusion}

Our study is the first to show variation in phenotypic and genotypic between CA- and HA-MRCoPS in the central region of the Kingdom of Saudi Arabia. The MRCoPS occurrence rate in the Kingdom of Saudi Arabia is extensively high, with a substantial amount of the cases noticed in the central region of the country, specified the multi-national environment of the population in that area and the circumstance that this region signifies a very demanding marketable for people from all over the world. The conclusions of this study stress the vital would like for broad screening, precautionary, and educational methods to accomplish the cumulative MRSA prevalence rate. Meanwhile, this present study comprised studies that concealed the central region of the country, forthcoming studies that cover the whole country are suggested to spectacle the complete picture of MRCoPS prevalence among CA- and HA-MRCoPS in the Kingdom of Saudi Arabia.

\section{Abbreviations}

CA

Community acquired; HA:Hospital acquired; CoPS:Coagulase positive staphylococcus; CoNS:Coagulase negative staphylococcus; MRCOPS:methicillin resistant coagulase positive staphylococcus; SDS:Sodium dodecyl sulfate; MHA:Muller Hinton agar; CFU:Colony forming unit; PVL:Panton-Valentine leukocidin; spa:Staphylococcus protein A.

\section{Declarations}

Ethics approval and consent to participate-The study was conducted according to the guidelines of the Declaration of Helsinki and approved by the Institutional Review Board of King Abdullah International Medical Research Center (Ref. No. IRBC/1010/18). Approved informed consent was used and obtained from all participants involved in this study. 
Consent publication-Individual data such as images and videos did not accompany this particular manuscript and hence consent for publication is not applicable.

Availability of Data and materials-The datasets used and analyzed during the current study are available from the corresponding author on reasonable request.

Competing interests- The authors declare that they have no competing interests for this work.

Funding-This research was funded by King Abdullah International Medical Research Center (KAIMRC), Riyadh, Kingdom of Saudi Arabia. Grant number RYD-16-417780-75574. Research protocol RC13/240/R.

Author Contributions-H.A. and S.J. conceptualized, planned, and supervised the study; N.K., H.S., and D.K. collected consent form, questionnaire, and the samples, performed the phenotypic laboratory analysis, and compiled the data; S.A., W.W., N.B., E.O. and R.E. performed the molecular genetic laboratory analysis and compiled the data; H.A and S.J. analyzed and interpreted the data; H.A. wrote the draft manuscript; S.J. critically reviewed and edited the manuscript; All authors have read and agreed to the published version of the manuscript.

Acknowledgment-We are grateful to King Saud Bin Abdulaziz University for health sciences faculty member's students, and staffs for their contribution to this research work. Also King Abdullah Medical City Hospital, Riyadh, Saudi Arabia, staffs and study participants for their contribution to this research work.

\section{References}

1. Bertrand X. Methicillin-resistant Staphylococcus aureus: A never emerging threat. Therapy, 2010. 7: p. $169-78$.

2. McKinnell, J.A., et al., A systematic literature review, and meta-analysis of factors associated with methicillin-resistant Staphylococcus aureus colonization at the time of hospital or intensive care unit admission. Infection control and hospital epidemiology, 2013. 34(10): p. 1077-1086.

3. Grundmann, H., et al., Emergence and resurgence of methicillin-resistant Staphylococcus aureus as a public-health threat. The Lancet, 2006. 368(9538): p. 874-885.

4. Uhlemann, A.-C., et al., Evolution of community-and healthcare-associated methicillin-resistant Staphylococcus aureus. Infection, genetics and evolution, 2014. 21: p. 563-574.

5. Kluytmans-Vandenbergh, M. and J. Kluytmans, Community-acquired methicillin-resistant Staphylococcus aureus: current perspectives. Clinical Microbiology and Infection, 2006. 12: p. 9-15.

6. Carleton, H.A., et al., Community-adapted methicillin-resistant Staphylococcus aureus (MRSA): population dynamics of an expanding community reservoir of MRSA. The Journal of infectious diseases, 2004. 190(10): p. 1730-1738.

7. Charlebois, E.D., et al., Population-based community prevalence of methicillin-resistant Staphylococcus aureus in the urban poor of San Francisco. Clinical Infectious Diseases, 2002: p. $425-433$. 
8. Al-Anazi, A.R., Prevalence of methicillin-resistant Staphylococcus aureus in a teaching hospital in Riyadh, Saudi Arabia. Journal of Biomedical Research, 2009; 20(1): p.7-14.

9. Haddad, Q., et al., Outbreak of methicillin-resistant Staphylococcus aureus in a neonatal intensive care unit. Journal of Hospital Infection, 1993. 23(3): p. 211-222.

10. Zaman, R. and W. Dibb, Methicillin-resistant Staphylococcus aureus (MRSA) isolated in Saudi Arabia: epidemiology and antimicrobial resistance patterns. Journal of Hospital Infection, 1994. 26(4): p. 297-300.

11. Alghaithy, A., et al., Nasal carriage and antibiotic resistance of Staphylococcus aureus isolates from the hospital and non-hospital personnel in Abha, Saudi Arabia. Transactions of the Royal Society of Tropical Medicine and Hygiene, 2000. 94(5): p. 504-507.

12. Alrabiah, K., et al., Characteristics and risk factors of hospital-acquired-methicillin-resistant Staphylococcus aureus (HA-MRSA) infection of pediatric patients in a tertiary care hospital in Riyadh, Saudi Arabia. International Journal of pediatrics and adolescent medicine, 2016. 3(2): p. 71-77.

13. Alaklobi, F., et al., The prevalence of community-associated methicillin-resistant Staphylococcus aureus among outpatient children in a tertiary hospital: A prospective observational study in Riyadh, Saudi Arabia. International Journal of Pediatrics and Adolescent Medicine, 2015. 2(3-4): p. 136-140.

14. Tayfour, M.A., F.N. Eris, and A.R. Alanazi, Comparison of antibiotic susceptibility tests, plasmid profiles and restriction enzyme analysis of plasmid DNA of methicillin-susceptible and resistantStaphylococcus aureus strains isolated from intensive care units. Saudi medical journal, 2005. 26(1): p. 57-63.

15. Madani, T.A., et al., Methicillin-resistant Staphylococcus aureus in two tertiary-care centers in Jeddah, Saudi Arabia. Infection control and hospital epidemiology, 2001. 22(4): p. 211-216.

16. Bukharie, H.A., et al., Emergence of methicillin-resistant Staphylococcus aureus as a community pathogen. Diagnostic microbiology and infectious disease, 2001. 40(1-2): p. 1-4.

17. Austin, T.W., et al., MRSA prevalence in a teaching hospital in Western Saudi Arabia. Saudi medical journal, 2003. 24(12): p. 1313-1316.

18. Clinical and Laboratory Standards Institute (CLSI), Performance standards for antimicrobial susceptibility testing. M100, 28th Edition, January 2018.

19. Luteijn, J., et al., Diagnostic accuracy of culture-based and PCR-based detection tests for methicillinresistant Staphylococcus aureus: a meta-analysis. Clinical microbiology and infection, 2011. 17(2): p. 146-154. Doi: 10.1111/j.1469-0691.2010.03202. x.

20. Kotilainen, P., et al., Elimination of epidemic methicillin-resistant Staphylococcus aureus from a university hospital and district institutions, Finland. Emerging infectious diseases, 2003. 9(2): p. 169.

21. Sambrook, J., Fritsch EF Maniatis T 1989. Molecular cloning: a laboratory manual, 1989. 1: p. 7.1917.29 .

22. Vannuffel, P., et al., Specific detection of methicillin-resistant Staphylococcus species by multiplex PCR. Journal of clinical microbiology, 1995. 33(11): p. 2864-2867. 
23. Mehndiratta, P., et al., Molecular typing of methicillin-resistant Staphylococcus aureus strains by PCRRFLP of SPA gene: a reference laboratory perspective. Indian Journal of Medical Microbiology, 2009. 27(2): p. 116.

24. Al-Ruaily, M.A. and O.M. Khalil, Detection of (mecA) gene in methicillin-resistant Staphylococcus aureus (MRSA) at Prince a/Rhman Sidery hospital, al-Jouf, Saudi Arabia. Journal of Medical Genetics and Genomics, 2011. 3(3): p. 41-45.

25. Milheiriço, C., D.C. Oliveira, and H. de Lencastre, Update to the multiplex PCR strategy for assignment of mec element types in Staphylococcus aureus. Antimicrobial agents and chemotherapy, 2007. 51(9): p. 3374-3377.

26. Heilmann, C., et al., The multifunctional Staphylococcus aureus autolysin aaa mediates adherence to immobilized fibrinogen and fibronectin. Infection and immunity, 2005. 73(8): p. 4793-4802. Doi: 10.1128/IAI.73.8.4793-4802.2005.

27. Schaeffer, C.R., et al., Accumulation-associated protein enhances Staphylococcus epidermidis biofilm formation under dynamic conditions and is required for infection in a rat catheter model. Infection and immunity, 2015. 83(1): p. 214-226. Doi: 10.1128/IAI.02177-14.

28. Srednik, M.E., et al., Biofilm formation and antimicrobial resistance genes of coagulase-negative staphylococci isolated from cows with mastitis in Argentina. FEMS microbiology letters, 2017. 364(8): p. fnx001. https://doi.org/10.1093/femsle/fnx001.

29. Arciola, C.R., L. Baldassarri, and L. Montanaro, Presence of icaA and icaDGenes and slime production in a collection of Staphylococcal strains from catheter-associated infections. Journal of clinical microbiology, 2001. 39(6): p. 2151-2156. Doi: 10.1128/JCM.39.6.2151-2156.2001.

30. McClure, J.-A., et al., Novel multiplex PCR assay for detection of the staphylococcal virulence marker Panton-Valentine leukocidin genes and simultaneous discrimination of methicillin-susceptible fromresistant staphylococci. Journal of clinical microbiology, 2006. 44(3): p. 1141-1144. Doi: 10.1128/JCM.44.3.1141-1144.2006.

31. Al-Hamad, A.M., et al., Incidence and antibiotic susceptibility of MRSA infections in a Saudi Arabian hospital: a 10-year surveillance study. The Journal of Infection in Developing Countries, 2018. 12(06): p. 454-461. Doi:10.3855/jidc.9778.

32. Sirkhazi, M., et al., Bacterial spectrum, isolation sites and susceptibility patterns of pathogens in adult febrile neutropenic cancer patients at a specialist hospital in Saudi Arabia. World journal of oncology, 2014. 5(5-6): p. 196.

33. Naeem, M., E. Al Banyan, and S.T. Sindhu, Methicillin-resistant Staphylococcus aureus colonization is not associated with a higher rate of admission to the pediatric intensive care unit. The American journal of emergency medicine, 2013. 31(4): p. 727-729.

34. Shady, H.M.A., et al., Staphylococcus aureus nasal carriage among outpatients attending primary health care centers: a comparative study of two cities in Saudi Arabia and Egypt. Brazilian Journal of Infectious Diseases, 2015. 19(1): p. 68-76. 
35. Albarrag, A., et al., Prevalence and Molecular Genetics of Methicillin-Resistant Staphylococcus aureus Colonization in Nursing Homes in Saudi Arabia. Canadian Journal of Infectious Diseases and Medical Microbiology, 2020. 2020: p.1-6. Doi:10.1016/j.ijpam.2016.03.006.

36. Abujheisha, K.Y., Prevalence of Methicillin-Resistant Staphylococcus aureus (MRSA) in the Community of Al-Majmaah/Saudi Arabia and Possibility of Resistance to Vancomycin and other Antimicrobial Agents. Eye, 2013. 2: p. 60.87. https://doi.org/10.1155/2020/2434350.

37. Albusayes, N.N., et al., Prevalence and factors associated with methicillin-resistant Staphylococcus aureus colonization among clinical medical students. Journal of Nature and Science of Medicine, 2019. 2(4): p. 226. Doi:10.5923/j.microbiology.20130301.06.

38. Bastidas, C. A., et al., Antibiotic susceptibility profile and prevalence of mecA and lukS-PV/lukF-PV genes in Staphylococcus aureus isolated from nasal and pharyngeal sources of medical students in Ecuador. Infection and Drug Resistance, 2019. 12: p. 2553-2560. doi: 10.2147/IDR.S219358.

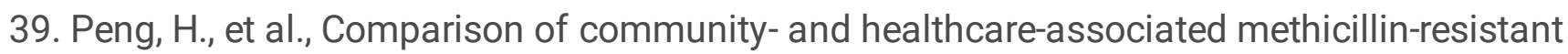
Staphylococcus aureus isolates at a Chinese tertiary hospital, 2012-2017. Scientific Report, 2018. 8: p. 17916. Doi:10.1038/s41598-018-36206-5.

40. Bai, Z., et al., Identification of Methicillin-Resistant Staphylococcus Aureus From Methicillin-Sensitive Staphylococcus Aureus and Molecular Characterization in Quanzhou, China. Frontiers in Cell and Developmental Biology, 2021. 9: p. 6. https://doi.org/10.3389/fcell.2021.62968.

41. Shariati, A., et al., The global prevalence of Daptomycin, Tigecycline, Quinupristin/Dalfopristin, and Linezolid-resistant Staphylococcus aureus and coagulase-negative staphylococci strains: a systematic review and meta-analysis. Antimicrobial Resistance \& Infection Control, 2020. 9: p. 1-20. https://doi.org/10.1186/s13756-020-00714-9.

42. Gostelow, M., et al., Pharmacokinetics and safety of recently approved drugs used to treat methicillinresistant Staphylococcus aureus infections in infants, children, and adults. Expert review of clinical pharmacology, 2014. 7(3): p. 327-340.

43. Amberpet, R., et al., Detection of heterogeneous vancomycin-intermediate Staphylococcus aureus: a preliminary report from south India. The Indian journal of medical research, 2019. 150(2): p. 194. Doi: 10.4103/ijmr.IJMR_1976_17.

44. Guo, Y., et al., Prevalence and therapies of antibiotic-resistance in Staphylococcus aureus. Frontiers in cellular and infection microbiology, 2020. 10: p. 107. Doi: 10.3389/fcimb.2020.00107.

45. Abulreesh, H.H., et al., Prevalence of antibiotic resistance and virulence factors encoding genes in clinical Staphylococcus aureus isolates in Saudi Arabia. Clinical epidemiology and global health, 2017. 5(4): p. 196-202.

46. Omar, N.Y., et al., Molecular typing of methicillin-resistant Staphylococcus aureus clinical isolates on the basis of protein A and coagulase gene polymorphisms. International journal of microbiology, 2014. 2014: p 1-11. http://dx.doi.org/10.1155/2014/650328.

47. Goh, S.-H., et al., Molecular typing of Staphylococcus aureus on the basis of coagulase gene polymorphisms. Journal of Clinical Microbiology, 1992. 30(7): p. 1642-1645. 
48. Saei, H.D. and M. Ahmadi, Discrimination of Staphylococcus aureus isolate on the basis of gene coding protein A using PCR-restriction enzyme analysis. Comparative Clinical Pathology, 2012. 21(5): p. $645-652$.

49. Frenay, H., et al., Discrimination of epidemic and nonepidemic methicillin-resistant Staphylococcus aureus strains on the basis of protein A gene polymorphism. Journal of clinical microbiology, 1994. 32(3): p. 846-847.

50. Diep, B.A., et al., Complete genome sequence of USA300, an epidemic clone of community-acquired meticillin-resistant Staphylococcus aureus. The Lancet, 2006. 367(9512): p. 731-739.

51. Enright, M.C., Genome of an epidemic community-acquired MRSA. Lancet (London, England), 2006. 367(9512): p. 705-706. Doi: 10.1016/S0140-6736(06)68233-0. PMID: 16517254.

52. Bukharie, H.A., A review of community-acquired methicillin-resistant Staphylococcus aureus for primary care physicians. Journal of family and community medicine, 2010. 17(3): p. 117. Doi: 10.4103/1319-1683.74320.

53. Craft, K.M., et al., Methicillin-resistant Staphylococcus aureus (MRSA): antibiotic-resistance and the biofilm phenotype. MedChemComm, 2019. 10(8): p. 1231-1241. Doi: 10.1039/c9md00044e.

54. Salgueiro, V.C., et al. Methicillin resistance and virulence genes in invasive and nasal Staphylococcus epidermidis isolates from neonates. BMC Microbiology,2017. 17: p. 15. https://doi.org/10.1186/s12866-017-0930-9.

55. Büttner, H., et al., A Giant Extracellular Matrix Binding Protein of Staphylococcus epidermidis Binds Surface-Immobilized Fibronectin via a Novel Mechanism. Mbio, 2020. 11(5). https:// doi.org/10.1128/mBio.01612-20.

56. Skovdal, S.M., et al., Host factors abolish the need for polysaccharides and extracellular matrixbinding protein in Staphylococcus epidermidis biofilm formation. Journal of Medical Microbiology, 2021: p. 001287. doi: 10.1099/jmm.0.001287.

57. Büttner, H., D. Mack, and H. Rohde, Structural basis of Staphylococcus epidermidis biofilm formation: mechanisms and molecular interactions. Frontiers in cellular and infection microbiology, 2015. 5 : p. 14.

58. Salgueiro, V.C., et al., Methicillin resistance and virulence genes in invasive and nasal Staphylococcus epidermidis isolates from neonates. BMC microbiology, 2017. 17(1): p. 1-10. Doi: 10.1186/s12866017-0930-9.

59. França, A., et al., Virulence factors in coagulase-negative staphylococci. Pathogens, 2021. 10(2): p. 170. Doi: $10.3390 /$ pathogens 10020170.

60. Omidi, M., et al., Ability of biofilm production and molecular analysis of spa and ica genes among clinical isolates of methicillin-resistant Staphylococcus aureus. BMC research notes, 2020. 13(1): p. 1-7. Doi: 10.1186/s13104-020-4885-9.

61. Tan, X., et al., A Novel Ivermectin-Derived Compound D4 and Its Antimicrobial/Biofilm Properties against MRSA. Antibiotics, 2021. 10(2): p. 208. Doi: 10.3390/antibiotics10020208. 
62. Gajewska, J. and W. Chajęcka-Wierzchowska, Biofilm Formation Ability and Presence of Adhesion Genes among Coagulase-Negative and Coagulase-Positive Staphylococci Isolate from Raw Cow's Milk. Pathogens, 2020. 9(8): p. 654. Doi:10.3390/pathogens9080654.

63. Cunha, R.C., et al., Staphylococcal slime layers and biofilm from different origins. Ciência Rural, 2019. 49(5).

64. Foster, T.J., Surface Proteins of Staphylococcus epidermidis. Frontiers in Microbiology, 2020. 11: p. 1829. https://doi.org/10.3389/fmicb.2020.01829.

65. Darboe, S., et al., Prevalence of Panton-Valentine leukocidin (PVL) and antimicrobial resistance in community-acquired clinical Staphylococcus aureus in an urban Gambian hospital: an 11-year period retrospective pilot study. Frontiers in cellular and infection microbiology, 2019. 9: p. 170. https://doi.org/10.3389/fcimb.2019.00170.

66. Özekinci, T., et al., Panton-Valentine leukocidin in community and hospital-acquired Staphylococcus aureus strains. Biotechnology \& Biotechnological Equipment, 2014. 28(6): p. 1089-1094. doi: 10.1080/13102818.2014.976457.

67. Bazzi, A.M., et al., Prevalence of Panton-Valentine leukocidin-positive methicillin-susceptible Staphylococcus aureus infections in a Saudi Arabian hospital. Journal of infection and public health, 2015. 8(4): p. 364-368. Doi: 10.1016/j.jiph.2015.01.010.

68. Anwar, K., D. Hussein, and J. Salih, Antimicrobial Susceptibility Testing and Phenotypic Detection of MRSA Isolated from Diabetic Foot Infection. International Journal of General Medicine, 2020. 13: p. 1349. Doi: 10.2147/IJGM.S278574.

69. Mottola, C., et al., Molecular typing, virulence traits and antimicrobial resistance of diabetic foot staphylococci. Journal of biomedical science, 2016. 23(1): p. 1-10. Doi:10.1186/s12929-016-0250-7.

70. Pobiega, M., et al., Virulence potential of Staphylococcus aureus strains isolated from diabetic foot ulcers among patients from southern Poland. Current vascular pharmacology, 2016. 14(6): p. 547551. 